\title{
Clinton's farewell gift to US science agencies
}

Washington

President Bill Clinton's eighth and last budget proposal - submitted to Congress on Monday (7 February) — would give several US science agencies a larger increase than any of his previous budgets.

"The president has proposed a historic science and technology budget for 2001," said Neal Lane, Clinton's science adviser, setting out details of a package announced by the president in a speech at the California Institute of Technology last month (see Nature 403, 349; 2000). "I believe it will generate bipartisan momentum to put the science and technology budget on the right track for future years."

But the budget package as a whole has met with a hostile reception in Congress where the Republicans control both Houses - as it would raise overall government spending by 4 per cent above previously agreed limits. "The president is proposing the era of big government come back with a vengeance," said Senator Pete Domenici (Republican, New Mexico), chair of the Senate Budget Committee.

As announced last month, Clinton's budget for 2001 would increase funding for the National Science Foundation (NSF), the biggest funder of non-biomedical research in US universities, by 17 per cent to $\$ 4.6$ billion. The National Institutes of Health $(\mathrm{NIH})$ would get a 6 per cent rise, to $\$ 18.8$ billion.

It emerged on Monday that the proposal would also raise spending on non-weapons research and development at the Department of Energy (DoE) by 15 per cent, to $\$ 4.2$ billion, and at the space agency NASA by 6 per cent, to $\$ 5.2$ billion. Of the main science agencies, only the Pentagon has been left out of the bonanza: its proposed budget for basic and applied research would fall by 5 per cent, to $\$ 4.6$ billion.

Lane says that the increase at the NSF and other agencies is intended to allow them to catch up with the NIH's rapid expansion. "It begins to restore the balance between biomedical research and the rest of the portfolio," he says.

Half of the NSF's proposed $\$ 675$ million increase would be available for general grant awards. "Over $\$ 300$ million is not tied to any specific initiative," says NSF director Rita Colwell. "This gives us the flexibility we've been seeking for years."

At the DoE, however, half of the proposed $\$ 340$ million increase for non-weapons research is earmarked for the construction of the Spallation Neutron Source at the Oak Ridge National Laboratory in Tennessee. Core programmes in physical research at the department receive small increases of 4 per cent or less.

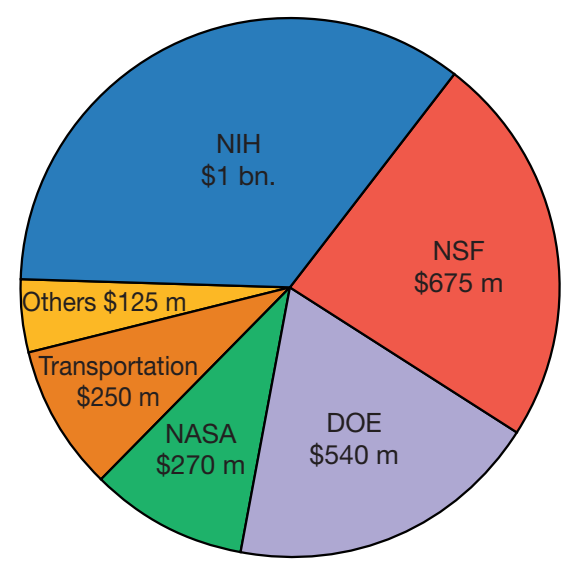

Jam tomorrow: how Clinton's budget proposal would share money among the science agencies.

Research grants make up $\$ 610$ million of the NIH's proposed total increase of $\$ 1$ billion. But the president's budget calls for fewer new intramural grants than in each of the past two years. The administration is focusing on continuing funding for grants already made.

Ruth Kirschstein, acting director of the $\mathrm{NIH}$, explains that the NIH is emphasizing new centres through programmes such as the Biomedical Information Science and Technology Initiative, which funds computational biology and bioinformatics. New money for such centres makes up $\$ 90$ million of the agency's increase.

NASA gets a raise for the first time in seven years, with its overall request up 3 per cent to $\$ 14$ billion, and projected to climb to $\$ 15.5$ billion by 2005. Administrator Dan Goldin will use the money for science and technology, space shuttle safety, and personnel. Space science gets nearly half of this year's $\$ 435$ million increase, giving it a budget of $\$ 2.4$ billion.

Goldin says he sees NASA "returning to its roots - cutting edge, fundamental R\&D”. Spending on science, aeronautics and technology, which accounted for only 31 per cent of the agency's budget in 1991, will reach 51 per cent within five years, he says. Goldin and Colwell each hinted that a major collaboration will soon be announced between their respective agencies, probably involving environmental research.

Taking into account the tens of billions of dollars' worth of development work performed by the Pentagon, the final Clinton budget would achieve a target set by the administration in 1993: to spend more on non-military than military research and development. At the height of the Cold War, military spending accounted for 70 per cent of the total, and in 1993 it still outscored civilian research by 60:40. Colin Macilwain, Tony Reichhardt and Paul Smaglik

\section{Mostly winners — but the NIF must make do}

- The National Science Foundation will lead an interagency nanotechnology initiative, which will double research spending in this growing field to $\$ 500$ million. Another interagency initiative would boost spending on computing research from $\$ 1.7$ billion to $\$ 2.3$ billion. The administration says that both projects will support basic research, not technology development.

- The nuclear weapons research programme gets a $\$ 300$ million boost, taking its budget to $\$ 4.6$ billion. But there is no extra money for completion of the troubled National Ignition Facility (NIF) at the Lawrence Livermore National Laboratory in California. Bill Richardson, the energy secretary, repeated that any extra

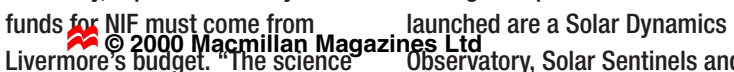
Livermore's budget. "The science Observatory, Solar Sentinels and a is sound" at NIF, Richardson said, "but the management stinks".

- NASA's hapless Mars programme gets a much-needed boost: after scraping by on budgets of $\$ 200$ million to $\$ 250$ million for several years, the multi-mission Mars effort gets \$327 million. Of that, \$35 million will go for 'micromissions' and a Mars telecommunication network described by the agency as "a publicly accessible, live-video 'gateway' to Mars".

- The biggest space-science initiative will investigate the Sun and solar storms. NASA's 'Living With a Star' programme - a combination of new missions and enhancements to old ones - will cost \$511 million over five years. Among the spacecraft to be
Geospace Dynamics Network. Most of the money will go to the Goddard Space Flight Center in Maryland.

- The NIH will get \$47 million to start building a neuroscience centre on its Bethesda, Maryland, campus (see Nature 403, 123; 2000). The project would require another \$26 million in the 2002 budget to complete the first phase of a proposed $\$ 270$ million scheme that would include renovations and additions to existing buildings.

- The Centers for Disease Control and Prevention would receive a $\$ 202$ million increase, including $\$ 70$ million for the construction of three laboratories dedicated to research into agents that could be used in bioterrorism and lethal pathogens such as the Ebola virus and hantavirus. 